\title{
20. Water, women and marital violence in a Bangladesh village
}

\author{
K.M. Rabiul Karim \\ University of Rajshahi, Bangladesh \\ Maria Emmelin \\ Lund University, Sweden \\ Bernadette P. Resurreccion \\ Asian Institute of Technology, Thailand \\ Sarah Wamala \\ Swedish National Institute of Public Health, Sweden
}

The global water crisis has affected women and men in different ways. There is evidence that millions of women as a result carry a double burden of disadvantage from the water crisis (Wallace and Porter 2010; United Nations Development Programme (UNDP) 2006). In many instances, water development projects and water privatisation restrict women's access to water, further increasing their burden (UNDP 2006; Brown 2010). In rural Bangladesh, women are primarily responsible for domestic water use and men are mainly engaged in irrigation (Jordans and Zwarteveen 1997). Technology-intensive water development initiatives have, however, largely emphasised irrigation, thus facilitating men's water needs at the expense of women's (Sadeque 2000; Chadwick and Datta 1999).

\section{Gendered roles and marital violence in rural Bangladesh}

Marital male violence against women is widespread in rural Bangladesh. A recent study showed that almost 62 per cent of married women were subject to either physical or sexual violence by their husbands (García-Moreno et al. 2005). Women are not, however, abused randomly. Researchers mention many cases of wife battery being used as a punishment for failing to fulfill gendered household obligations (Baden et al. 1994; Bhuiya et al. 2003). In a recent study we explored 
the implications of a groundwater development project on women's workload and their exposure to marital violence (Karim et al. 2012). Fieldwork was conducted in a northwest Bangladesh village between July 2004 and July 2005.

\section{The water development project}

Groundwater was the only reliable source of water in the vicinity of the study village. There were three means of lifting groundwater: deep tube-wells (DTWs), shallow tube-wells (STWs) and hand pumps. DTWs and STWs are operated by motorised pumps and are exclusively used for irrigation, whereas shallow hand pumps are used for domestic purposes. In the dry season, however, only a few hand pumps lift water because of a lowering of the groundwater table (Jordans and Zwarteveen 1997). The project facilitated DTW-based irrigation, which contributed to an increase in the area's agricultural productivity; however, many households faced a domestic water shortage in the dry season because the extra irrigation further lowered the groundwater table.

\section{Gender roles, dry season water crisis and women's workload}

Women's water needs were mostly related to their domestic obligations, whereas men's water needs were mostly related to irrigation. The study estimated that, on average, a woman spent seven hours and 25 minutes daily on domestic waterrelated work, but a man spent only 19.2 minutes. In the dry season, to fulfill their obligations, women had to walk to distant wells, which resulted in an increase of their domestic workload (see Table 1). A number of women (15.1 per cent) also faced severe difficulties in fulfilling their obligations because of the extra time spent collecting water (see Table 1). Therefore, the development project actually reduced the ability of women to fulfill their normative gender role. 
Table 1: Survey of dry season water shortage, increased workload and women's difficulties

\begin{tabular}{|c|c|c|c|c|c|}
\hline & \multicolumn{2}{|l|}{$\mathbf{N}$} & \multicolumn{2}{|c|}{ Frequency } & Percentage \\
\hline $\begin{array}{l}\text { Households with domestic water } \\
\text { shortage }\end{array}$ & \multicolumn{2}{|l|}{196} & \multicolumn{2}{|l|}{87} & 44.4 \\
\hline $\begin{array}{l}\text { Women's water-collection time } \\
\text { increased }\end{array}$ & \multicolumn{2}{|c|}{$185^{*}$} & \multicolumn{2}{|l|}{102} & 55.1 \\
\hline Women's water-related workload & & & \multicolumn{2}{|c|}{ Mean (\%) } & Range \\
\hline $\begin{array}{l}\text { Normal water collection time } \\
\text { (minutes/trip) }\end{array}$ & \multicolumn{2}{|l|}{185} & \multicolumn{2}{|c|}{$14.35(7.63)$} & $02-35$ \\
\hline $\begin{array}{l}\text { Dry season water collection time } \\
\text { (minutes/trip) }\end{array}$ & \multicolumn{2}{|l|}{185} & \multicolumn{2}{|c|}{$18.75(10.4)$} & $02-45$ \\
\hline $\begin{array}{l}\text { Extra water collection time in the dry } \\
\text { season after project (minutes/day) }\end{array}$ & \multicolumn{2}{|l|}{185} & \multicolumn{2}{|c|}{$20.6(22.57)$} & $00-90$ \\
\hline $\begin{array}{l}\text { Extra water collection time following } \\
\text { the water development project } \\
\text { (minutes/day for affected women) }\end{array}$ & \multicolumn{2}{|l|}{102} & \multicolumn{2}{|c|}{$37.4(17.14)$} & $14-90$ \\
\hline \multirow{2}{*}{$\begin{array}{l}\text { Women's difficulty in fulfilling } \\
\text { obligations }\end{array}$} & \multicolumn{4}{|c|}{ Extra time spent (mins/day) } & $N=185(\%)$ \\
\hline & 0 & $<30$ & $30-59$ & $\geq 60$ & \\
\hline No/little & 77 & 26 & 8 & 0 & $111(60.0 \%)$ \\
\hline Moderate & 6 & 10 & 30 & 0 & $46(24.9 \%)$ \\
\hline Severe & 0 & 1 & 11 & 16 & $28(15.1 \%)$ \\
\hline
\end{tabular}

Source: Authors' research; adapted from Karim et al. 2012. * 11 households that did not have any female members who carried out water-related work were excluded.

\section{Women's obligations, increased workload, and marital violence}

Data indicated that women were obliged to unconditionally obey their husbands. A 36-year-old woman exemplified this obligation: 'but I made a mistake, as I argued with him ... .' The interviews also indicated that women were expected to manage time. A woman who had experienced violence said that it occurred as a punishment for failing to fulfill her household duties. It also illustrates how the lack of water contributed to make the situation worse: 
I went to fetch water ... It took a long time because there was a long line ... but when I came back, I saw that the man was home. He asked me to serve lunch .... I replied that it took a long time to collect water (as our nearest three hand pumps had dried out). But he said that it was my problem if other women can cook on time for their husbands! So when I told him to go to see the deep (DTW) ... he got angry and started beating me ... I did not argue anymore; rather I went to cook ...

The other informants supported a perception of marital violence being very common and justified, for a range of reasons such as burning the food while cooking, not having washed the husband's clothes, or not making palatable food. Because the water crisis meant that women had to walk to distant wells, sometimes several times in a day, it directly challenged the basic gendered norm system and increased the possibility of socially justified violence.

\section{Conclusion}

The water development project largely facilitated men's irrigation water needs by installing DTWs. Irrigation water became available all year, whereas the domestic water supply decreased. Many women thus walked to distant wells for domestic water collection, which increased their workload. This challenged their possibilities of fulfilling household obligations, thereby increasing the risk of normative marital male violence against women as a punishment for their failure.

In a patriarchal social context, a gender-blind water development project may have severe negative consequences on the lives of many women. We suggest that any water sector projects (e.g., irrigation, fisheries, or health and sanitation projects) should take women's contextual gendered roles and obligations and social aspects of marital violence into account. Before implementation, there is a need to explore how the development project may influence or be influenced by social norms that determine the relationship between men and women. At the same time, it is important for development interventions to challenge the existing gendered norm systems and to initiate a discussion within the community on gendered roles, rights and obligations.

Dr K.M. Rabiul Karim is Associate Professor in the Department of Social Work at the University of Rajshahi. This article is based on an article first published in Health Care for Women International titled 'Water development projects and marital violence: experiences from rural Bangladesh'. For more information, please contact Karim at rkarimsw@yahoo.com.

Dr Maria Emmelin is a Professor of Global Health at Lund University. 
Dr Bernadette P. Rescurreccion is Associate Professor in Gender and Development Studies at Asian Institute of Technology.

Dr Sarah Wamala is Director-General of the Swedish National Institute of Public Health.

\section{References}

Baden, S., Green, C., Goetz, A.M. and Guhathakurta, M., 1994. 'Background report on gender issues in Bangladesh', in BRIDGE (development - gender), Institute of Development Studies, Brighton.

Bhuiya, A.U., Sharmin, T. and Hanifi, S.M.A., 2003. 'Nature of domestic violence against women in a rural area of Bangladesh: implication for preventive interventions', Journal of Health, Population and Nutrition 21(1):48-54.

Brown, R., 2010. 'Unequal burden: water privatisation and women's human rights in Tanzania', Gender \& Development, 18(1):59-67.

Chadwick, M. and Datta, A., 1999. 'Water resource management in Bangladesh: a policy review', in Livelihood-Policy Relationships in South Asia, University of Leeds.

García-Moreno, C., Jansen, H.A.F.M., Ellsberg, M., Heise, L. and Watts, C., 2005. 'WHO multi-country study on women's health and domestic violence against women: initial results on prevalence, health outcomes and women's responses', World Health Organization, Geneva.

Jordans, E. and Zwarteveen, M., 1997. 'A well of one's own: gender analysis of an irrigation program in Bangladesh', Dhaka, International Irrigation Management Institute and Grameen Krishi Foundation.

Karim, K.M.R., Emmelin, M., Resurreccion, B. and Wamala, S., 2012. 'Water development projects and marital violence: experiences from rural Bangladesh', Health Care for Women International 33(3):200-16.

Sadeque, S.Z., 2000. 'Nature's bounty or scarce commodity: competition and consensus over groundwater use in rural Bangladesh', in B.R. Bruns and R.S. Meinzen-Dick (eds), Negotiating Water Rights, Intermediate Technology Publications, London: pp. 269-91.

United Nations Development Programme (UNDP), 2006. Beyond Scarcity: Power, poverty and the global water crisis, New York.

Wallace, T. and Porter, F., 2010. 'Introduction', Gender \& Development 18(1):1-10. 
This text taken from Global Water: Issues and Insights by R. Quentin Grafton, Paul Wyrwoll, Chris White and David Allendes, published May 2014 by ANU Press, The Australian National University, Canberra, Australia. 